\title{
Discoveries of microfossils of Fe- oxidizing bacteria in 3.46 Ga- and 3.35 Ga-old cherts from Pilbara, Western Australia
}

\author{
USCHI M GRAHAM ${ }^{1}$, KENICHIRO SUGITANI ${ }^{2}$ AND \\ HIROSHI OHMOTO ${ }^{3}$
}

${ }^{1}$ University of Kentucky

${ }^{2}$ Nagoya University

${ }^{3}$ Penn State University

Presenting Author: graham@topasol.com

Researchers have speculated that, prior to $\sim 1.8 \mathrm{Ga}$ ago, anaerobic and anoxygenic photoautotrophic iron-oxidizing bacteria $(\mathrm{Fe}-\mathrm{OB})$ were the dominant organisms on Earth and produced banded iron formations. Microfossils have been discovered by previous investigators in several Archean formations, but their specific genomic types have not been identified, because the studies relied primarily on the morphologies of microfossils. The oldest definitive fossils of FeOB previously reported were found in 2.4 Ga-old stromatolites in India (Crosby et al., 2015). Here we report the discoveries of microfossils of aerobic Fe-OB in: (1) the 3.46 Ga-old Marble Bar Chert (MBCM), which deposited by submarine hydrothermal fluids on a deep $(>2.5 \mathrm{~km})$ ocean floor, and (2) the 3.35 Ga-old Strelley Pool Chert (SPC), which deposited in a shallow evaporating basin. We have identified the microfossils of $\mathrm{Fe}-\mathrm{OM}$ through three-dimensional imaging and chemical analyses utilizing high-resolution scanning transmission microscopy (STEM) and energy-loss spectroscopy (EELS). The analyses have revealed carbon nano-architectures of the cells, as well as copious nanocrystals of iron oxide on and inside of the cell structures. Fe-OM microfossils in the MBCM are ellipsoidal tubular shapes, typically $\sim 0.2 \mathrm{x} 1 \mu \mathrm{m}$ in size. The Fe-OM in the SPC are much bigger (typically $\sim 20 \times 200 \mu \mathrm{m}$ in size), yet they have essentially the same internal structures and associations with Fe-oxide nanocrystals. Based on the various geochemical data on the host cherts (e.g., Mo, U, W, Ce/Ce*, Y/Ho) and the abundance of submicron-sized hematite crystals in the host cherts, we interpret that the $\mathrm{Fe}-\mathrm{OB}$ in the $\mathrm{MBCM}$ were chemolithoautotrophs and those in the SPC were photoautotrophs; they utilized $\mathrm{Fe}^{2+}$ from the lower pools and $\mathrm{CO}_{2}$ and $\mathrm{O}_{2}$ from the overlying water in biosynthesis, much like today's Fe-OB. Our study suggests that both oxygenic photoautotrophs (cyanobacteria) and $\mathrm{O}_{2}$-utilizing $\mathrm{Fe}-\mathrm{OM}$ had evolved, and the ocean-atmosphere system had become fully oxygenated by $3.5 \mathrm{Ga}$ ago. 